\title{
The NK1 Receptor Is Essential for the Full Expression of Noxious Inhibitory Controls in the Mouse
}

\author{
Hervé Bester, ${ }^{1}$ Carmen De Felipe, ${ }^{2}$ and Stephen P. Hunt ${ }^{1}$ \\ ${ }^{1}$ Department of Anatomy and Developmental Biology, University College London, London WC1E 6BT, United Kingdom, \\ and 2Instituto de Neurociencias, Universidad Miguel Hernández, 03550 San Juan, Alicante, Spain
}

Behavioral analysis of the NK1 receptor gene knock-out (NK1-/-) mouse indicated that substance $P$ was closely involved in orchestrating the physiological and behavioral response of the animal to major environmental stressors. In particular, endogenous pain control mechanisms, such as stressinduced analgesia were substantially impaired in mutant mice, suggesting a reduction in descending inhibitory controls to the spinal cord from the brainstem. To directly test the integrity of descending controls in NK1-/- mice, we have analyzed c-Fos expression in laminae I-II of the lumbar and cervical cord and in the rostral ventromedial medulla in an experimental paradigm known to require recruitment of descending inhibitory controls. Anesthetized mice were stimulated with water at $50^{\circ} \mathrm{C}$ either on their forepaw, hindpaw, or on both the hindpaw plus forepaw concurrently. Wild-type mice, naïve or treated with an NK1 antagonist (RP67580) or its inactive isomer (RP68651), were compared with NK1-/- mice. C-Fos expression at the lumbar laminae I-Il level was significantly reduced, whereas it was significantly greater in the raphe magnus and pallidus nuclei in the double stimulation situation in wild-type compared with NK1-/- mice. Blocking the NK1 receptor pharmacologically reproduced, in an enantiomere-selective manner, the data from NK1-/- mice, with no evidence for recruitment of descending inhibition at the lumbar cord level after forepaw stimulation. The present study demonstrates that the NK1 receptor is essential for the full development of noxiously evoked descending inhibition.

Key words: NK1 receptor; DNIC; laminae I-II; c-Fos; nociception; knock-out
Chemical or electrical stimulation of certain brain areas can produce powerful antinociception mediated by activation of descending pathways generally involving the ventral brainstem (Jones and Gebhart, 1988; Jones and Light, 1990; Fields, 2000). It has also been known for some years that these antinociceptive pathways can be recruited by a noxious stimulus applied far outside the receptive field of a nociceptive dorsal horn neuron (Le Bars et al., 1979; Roby Brami et al., 1987). This results in a dramatic reduction of the noxiously evoked response of the recorded neuron. This phenomenon of diffuse noxious inhibitory control (DNIC) was first described electrophysiologically at the level of deep dorsal horn wide dynamic range (WDR) neurons (Le Bars et al., 1979) and recently extended to rat lamina I nociceptive-specific (NS) neurons that project to the parabrachial area (Bester et al., 2000). Similar observations were also made for spinothalamic and less well defined dorsal horn NS neurons, although few were shown to be in superficial laminae (Gerhart et al., 1981; Tomlinson et al., 1983; Ness and Gebhart, 1991). DNIC has also been demonstrated in the rat by monitoring the c-Fos expression in response to hindpaw pinch stimulation in the presence of a concurrent noxious tail heat stimulus (Morgan et al., 1994) and in the rat pup (Boucher et al., 1998).

From experimental analysis of the NK1 receptor gene knockout (NK1-/-) mice (De Felipe et al., 1998) we suspected that DNIC might be significantly impaired in these animals. First,

Received Oct. 4, 2000; revised Oct. 30, 2000; accepted Nov. 13, 2000.

This work was supported by the Wellcome Trust and the Fondation Cino et Simone Del Duca. We thank A. Sheasby for technical assistance.

Correspondence should be addressed to Dr. Hervé Bester, Department of Anatomy and Developmental Biology, University College London, Medawar Building, Malet Place, London WC1E 6BT, UK. E-mail: h.bester@ucl.ac.uk.

Copyright (C) 2001 Society for Neuroscience 0270-6474/01/211039-08\$15.00/0 there was a loss of stress-induced analgesia in mutant mice. Second, we noted that there was an increased sensitivity to mechanical stimulation of the hindpaw contralateral to an inflammation generated by injection of complete Freund's adjuvant into the hindpaw. This could also have been explained by bilateral disruption of descending pathways. Finally, we noted that the antinociceptive effects of intraperitoneal morphine were reduced in the tail flick assay in $\mathrm{NK} 1-/-$ mice. This result could have resulted from the loss of descending inhibitory input from the rostroventral medulla (RVM) because injection of morphine into the RVM is known to generate profound analgesia (Foo and Helmstetter, 1999, 2000; Hurley and Hammond, 2000).

To address the hypothesis that substance P (SP) was involved in setting nociresponsive levels within the spinal cord, we monitored c-Fos expression in the superficial laminae of the dorsal horn and in the raphe nuclei of wild-type and $\mathrm{NK} 1-/-$ mice after noxious stimulation of the hindpaw or with simultaneous stimulation of the forepaw. Our analysis confirms that the NK1 receptor is essential for the full development of descending inhibitory controls on the spinal cord.

\section{MATERIALS AND METHODS}

Animals

Mice (C57B6x129/sv) in which the NK1 receptor gene had been disrupted at exon 1 were generated by homologous recombination. A total of 21 knock-out mice and 21 wild-type littermates were used for the different procedures. Animals were housed four or five per cage. Food and water were available ad libitum, and the mice were kept in a colony room with an ambient temperature of $22^{\circ} \mathrm{C}$ and a $12 \mathrm{hr}$ alternating light/dark cycle. The experiments were performed under the control of the British Animal Experimentation Inspectorate. 
Table 1. Averages ( \pm SEM) of the laminar distribution of the Fos-IR neurons at the lumbar level

Lumbar cord

\begin{tabular}{|c|c|c|c|c|c|c|c|c|c|c|}
\hline \multirow[b]{3}{*}{ Group } & \multirow[b]{3}{*}{ Mice } & \multicolumn{9}{|c|}{ Lumbar cord } \\
\hline & & \multicolumn{4}{|c|}{ Ipsilateral dorsal horn } & \multirow[b]{2}{*}{$\mathrm{X}$} & \multicolumn{4}{|c|}{ Contralateral dorsal horn } \\
\hline & & I-II & III-IV & $\mathrm{V}-\mathrm{VI}$ & $\mathrm{DH}+\mathrm{VH}$ & & I-II & III-IV & $\mathrm{V}-\mathrm{VI}$ & $\mathrm{DH}+\mathrm{VH}$ \\
\hline \multirow[t]{4}{*}{ HP } & wt & $27.1 \pm 2$ & $17.7 \pm 3.6$ & $19.9 \pm 1.9$ & $74 \pm 7.3$ & $5.3 \pm 0.5$ & $3.8 \pm 1.5$ & $12.1 \pm 2.5$ & $14.4 \pm 2.8$ & $40 \pm 8.2$ \\
\hline & ko & $30.2 \pm 4.6$ & $16.1 \pm 4.7$ & $12.7 \pm 3.4$ & $67.6 \pm 14.3$ & $4.5 \pm 1$ & $7 \pm 3.3$ & $9.4 \pm 2.6$ & $9 \pm 2.5$ & $31.2 \pm 9.3$ \\
\hline & wt RP67580 & $36.1 \pm 6.9$ & $23 \pm 4.4$ & $16.3 \pm 1.2$ & $87.6 \pm 6.1$ & $8.5 \pm 1.3$ & $7.9 \pm 1.5$ & $11.2 \pm 3.3$ & $10.9 \pm 2.3$ & $45.3 \pm 5.8$ \\
\hline & wt RP68651 & $39.5 \pm 5.2$ & $24 \pm 3.1$ & $23.3 \pm 2.2$ & $101.6 \pm 9.9$ & $7.3 \pm 1.3$ & $10.5 \pm 2.7$ & $13.6 \pm 1.3$ & $15.7 \pm 0.3$ & $53.3 \pm 3.3$ \\
\hline \multirow[t]{4}{*}{$\mathrm{FP}+\mathrm{HP}$} & wt & $12.3 \pm 2.2$ & $15.3 \pm 1.7$ & $12.4 \pm 2.9$ & $49.2 \pm 6.5$ & $5.6 \pm .8$ & $2.6 \pm 0.3$ & $12.4 \pm 1.7$ & $11.2 \pm 2.7$ & $36.4 \pm 6$ \\
\hline & ko & $31 \pm 2.6$ & $30.3 \pm 3$ & $19.3 \pm 1.9$ & $94.6 \pm 6.3$ & $6.3 \pm 0.7$ & $4.4 \pm 1$ & $24.7 \pm 3.9$ & $14.7 \pm 1.8$ & $54.4 \pm 7.9$ \\
\hline & wt RP67580 & $31.3 \pm 18$ & $17 \pm 1.7$ & $8.8 \pm 1$ & $61.8 \pm 4.7$ & $5.1 \pm 0.4$ & $5.3 \pm 1.3$ & $10.2 \pm 2$ & $5.7 \pm 1.2$ & $25.3 \pm 3.2$ \\
\hline & wt RP68651 & $23.8 \pm 1.7$ & $11.5 \pm 3.2$ & $7.6 \pm 3.1$ & $46.8 \pm 7.7$ & $2.6 \pm 0.7$ & $3.6 \pm 0.7$ & $7.2 \pm 2.4$ & $7.1 \pm 2.4$ & $22.5 \pm 6$ \\
\hline
\end{tabular}

I-II, III-IV, V-VI, X, Corresponding dorsal horn laminae. DH and VH, Dorsal and ventral horns, respectively. See Figure 1 for protocol abbreviations.

\section{C-Fos experiments}

Stimulation procedures. Animals of both genotypes (knock-out and wildtype) were divided into three groups of five individuals. Under fluothane (Mallinckrodt Veterinary, Uxbridge, UK) (1.5\% in oxygen) anesthesia, mice were stimulated by dipping their left hindpaw (HP) and/or forepaw (FP), accordingly to their group, in water from a thermostatically controlled bath set at $50^{\circ} \mathrm{C}$. Mice in the FP, HP, and FP + HP groups had the forepaw only, hindpaw only, and forepaw plus hindpaw stimulated, respectively. The stimulation durations were determined as follows: the FP group was stimulated for $40 \mathrm{sec}$; the HP group was stimulated for 10 sec; and the FP + HP group was stimulated for $10 \mathrm{sec}$ on the hindpaw while the forepaw was stimulated for $40 \mathrm{sec}$. In the latter procedure, hindpaw stimulation started $15 \mathrm{sec}$ after the start and ceased $15 \mathrm{sec}$ before the end of the forepaw stimulation.

Using the HP and FP + HP protocols, effects of the NK1 antagonist RP67580 and its inactive isomer RP68651 were investigated on four additional groups of wild-type mice. Both the antagonist and its inactive isomer were first diluted in DMSO, and further dilutions were made in distilled water. Under the same anesthesia regimen mice were intravenously injected (tail vein) with either the NK1 antagonist or its inactive isomer at a dose of $0.5 \mathrm{mg} / \mathrm{kg}$ in a volume of $0.1 \mathrm{ml}$ (De Felipe et al., 1998). An interval of $5 \mathrm{~min}$ was allowed before starting the stimulation procedures. Of the six mice injected with the NK1 antagonist, three were exposed to the HP and three to the FP + HP protocols. Of the six mice injected with the inactive isomer to the NK1 antagonist, three were exposed to the HP and three to the FP + HP protocols.

Immediately after the end of the stimulation period, mice were allowed to recover from anesthesia before going back in their boxes for 2 hr.

Perfusion. Two hours after stimulation, animals were terminally anesthetized with a $0.2 \mathrm{ml}$ intraperitoneal injection of pentobarbitone (Lethobarb; Solvay Duphar, Southampton UK). They were then perfused transcardially with heparinized PBS at $37^{\circ} \mathrm{C}$, followed by a solution of $4 \%$ paraformaldehyde, $0.05 \%$ picric acid in PBS $(0.15 \mathrm{M}, \mathrm{pH} 7.4)$ and then $20 \%$ sucrose in PBS $(0.15 \mathrm{M}, \mathrm{pH} 7.4)$, both at $10^{\circ} \mathrm{C}$. The brain and spinal cord were removed and cryoprotected overnight in a $30 \%$ sucrose solution. Transverse frozen sections $(50-\mu \mathrm{m}$-thick) were cut from the brainstem and from the lumbar and cervical cord. They were collected in three serial groups of free-floating sections.

C-Fos immunohistochemistry. All reactions were performed at room temperature on floating sections agitated on a shaker. Sections were incubated for $2 \mathrm{hr}$ in 3\% normal goat serum and $0.3 \%$ Triton X-100 in 0.15 м PBS (NGS-T-PBS). Then, sections were incubated overnight in a rabbit polyclonal antibody anti-c-fos (Ab-5; Calbiochem, La Jolla, CA) diluted in NGS-T-PBS $(1: 100,000)$. Sections were washed in 0.15 M PBS and incubated for $1 \mathrm{hr}$ in a goat anti-rabbit biotinylated antibody (Vector Laboratories, Burlingame, CA): 1:500 in NGS-T-PBS. Sections were washed again in $0.15 \mathrm{M}$ PBS and incubated for $2 \mathrm{hr}$ in avidin-biotin peroxidase complex (ABC Elite; Vectastain, Vector Laboratories). After washes in Tris buffer $(0.15 \mathrm{M}, \mathrm{pH} 7.6)$, sections were incubated for $2 \mathrm{~min}$ in a solution containing $0.05 \%$ of $3,3^{\prime}$ diaminobenzidine (DAB) and $0.2 \%$ ammonium nickel sulfate in $0.15 \mathrm{M}$ Tris buffer. Increasing doses of $\mathrm{H}_{2} \mathrm{O}_{2}$ were added every 5 min to obtain the following dilutions: 0.001 , $0.005,0.015,0.025$, and $0.075 \%$. Finally, the reaction was stopped by washes in Tris buffer. The sections were mounted on gelatin-coated slides and coverslipped.

\section{Counting of Fos-labeled cells}

At the spinal cord level. Fos-immunoreactive (Fos-IR) neurons were analyzed throughout the $\mathrm{L}_{2-6}$ and $\mathrm{C}_{4-8}$ spinal segments. Sections were first drawn with a camera lucida, noting the boundaries between the white and gray matter and the reticular part of the lamina $\mathrm{V}(\mathrm{Vr})$, as described in the rat (Molander et al., 1984). Under bright-field microscopy (objective $20 \times$ ), each Fos-IR neuron was drawn on the general boundary drawings obtained at the former step. The gray matter was divided into four ipsilateral and contralateral main domains: the superficial laminae I-II, the laminae III-IV, the deep laminae V-VI, and the ventral horn. Lamina $\mathrm{X}$ was also analyzed. For each mouse, every third section from the $\mathrm{L}_{2-6}$ and $\mathrm{C}_{4-8}$ segments was drawn, and Fos-IR neurons were counted. Counts from the 10 most labeled sections of the $\mathrm{L}_{2-6}$ and $\mathrm{C}_{4-8}$ segments were averaged, and the mean was used for further statistical analysis.

At the RVM level. Brainstem sections (150 $\mu \mathrm{m}$ apart) corresponding to sections ranging from -6.48 to $-5.34 \mathrm{~mm}$ from the bregma in the atlas of Franklin and Paxinos (1997) were systematically analyzed. Sections were drawn using a camera lucida attached to the microscope. The main outlines and Fos-IR neurons were first recorded. Then, the boundaries of the different raphe nuclei were overlaid on the drawings, according to the nearest corresponding section in the mouse brain atlas (Franklin and Paxinos, 1997). The following pontine nuclei were analyzed: gigantocellular reticular $(\mathrm{Gi})$, gigantocellular reticular pars $\alpha(\mathrm{GiA})$, lateral paragigantocellular reticular (LPGi), raphe magnus (RMg), and raphe pallidus $(\mathrm{RPa})$. The $\mathrm{RPa}$ nucleus was considered as a unique median structure, and because counts and distribution seemed similar on both sides for all the other nuclei, the counts made from both sides were added together. For each nucleus, the counts were averaged per section per animal, and the means were used for further statistical analysis. The experimenter was unaware of the mouse genotype at every step.

\section{Statistical analysis}

ANOVAs were made using Fisher's protected least significant difference tests (Statview 5; Macintosh, Abacus, UK). Results were expressed as mean number \pm SEM of Fos-IR neurons per section, for the five animals $(n=5)$ in each nontreated group and for three animals $(n=3)$ in the treated groups. Regression analyses were also used.

\section{Photomicrograph processing}

Illustrative sections were computerized on a Power G3 Macintosh using "Vision Explorer" software (Alliance Vision, Mirmande, France) from images grabbed through a CCD camera (JVC, London, UK) attached to the microscope. Digital information was then imported into Photoshop 5.5 for Macintosh (Adobe, London, UK) to adjust brightness and contrast and to produce montages. Final figures were made in FreeHand 8.1 for Macintosh (Macromedia, London, UK). 
HP

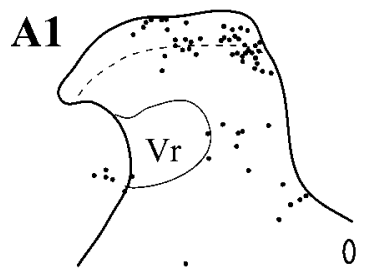

Laminae I-II

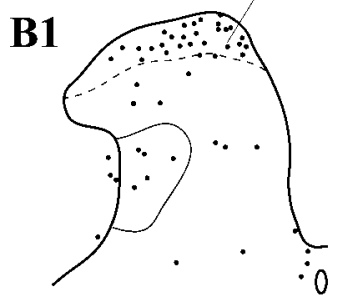

$500 \mu \mathrm{m}$

C1

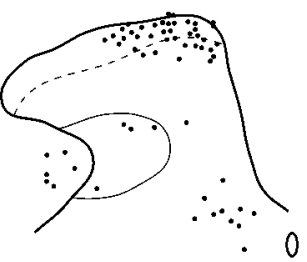

0

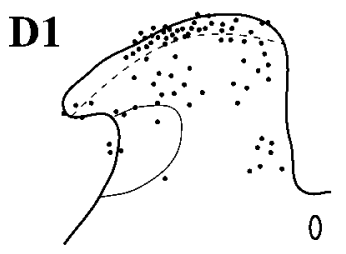

Figure 1. Representative examples of camera lucida drawings of Fos-IR neurons (black dots) in the lumbar dorsal horn ipsilateral to the stimulus in the hindpaw-stimulated animals (HP column) and in the forepaw plus hindpaw-stimulated animals (FP + HP column). $A$, Wild-type animals. $B$, NK1-/- mice. $C$, Wild-type animals injected with the RP67580 NK1 antagonist. $D$, Wild-type mice injected with the NK1 antagonist isomer RP68651. $V r$, Reticular part of the lamina V. Laminae I-II, Laminae I and II of the dorsal horn. Scale bar, $500 \mu \mathrm{m}$.

\section{RESULTS}

\section{C-Fos induction at the lumbar level}

\section{Effect of noxious heat applied to the hindpaw}

Noxious heat $\left(50^{\circ} \mathrm{C}, 10 \mathrm{sec}\right)$ applied to the hindpaw induced c-Fos expression mainly in the ipsilateral dorsal horn. The number of Fos-IR neurons induced in the ipsilateral dorsal horn, expressed as a percentage of the total dorsal horn Fos expression (both sides), was similar in wild-type and NK1-/- mice: $66 \pm 4$ and $71 \pm 5 \%$, respectively (Table 1 ). This expected side preference is greater if only laminae I-II are considered: $88.5 \pm 4$ and $81.2 \pm$ $6 \%$, respectively (Table 1 ).

Ten seconds of $50^{\circ} \mathrm{C}$ stimulation to the hindpaw induced Fos-IR neurons in all the dorsal horn laminae of the lumbar cord, in both wild-type and NK1-/- mice (Table 1, Fig. 1A1,B1). This stimulus was also effective in wild-type mice injected either with an NK1 antagonist or with its inactive isomer (Table 1, Fig. $1 C 1, D 1)$. The distribution of the Fos-IR neurons within the different laminae of the dorsal horn was similar between different groups (Fig. 1), as was the number of Fos-IR neurons in
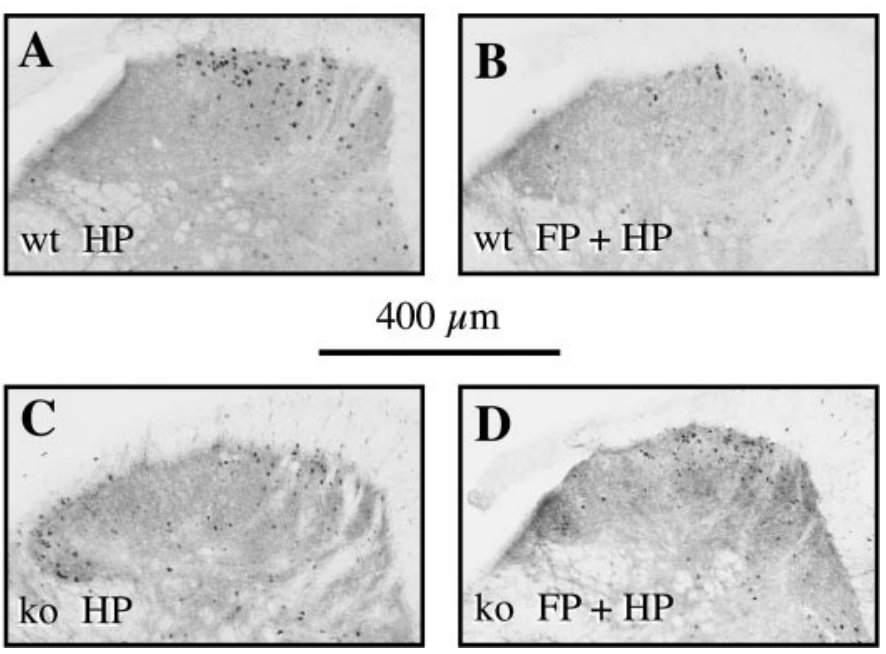

Figure 2. Photomicrographs of the lumbar dorsal horn (segments $\mathrm{L}_{4 / 5}$ ) ipsilateral to the stimulation. Note the reduction in the number of Fos-IR reactive neurons in wild-type animals $(A, B)$ between a hindpaw stimulation only $(A)$ and a forepaw plus hindpaw stimulation $(B)$, and the absence of such an effect in NK1-/- $(C, D)$. Scale bar, $400 \mu \mathrm{m}$.
A

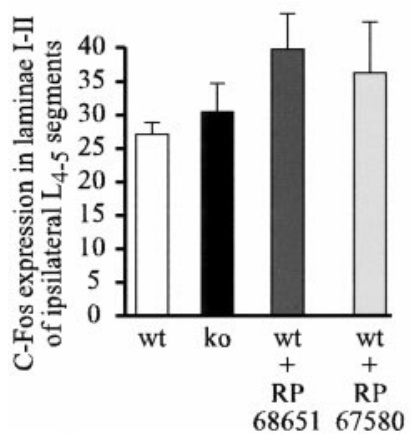

B

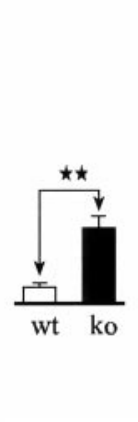

C

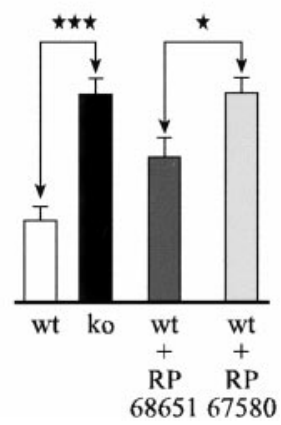

Figure 3. Histograms of the average number per section of Fos-IR neurons evoked in the lumbar laminae I-II, in the HP $(A), \mathrm{FP}(B)$, and FP + HP $(C)$ situations. $\star p<0.05 ; \star \star p<0.01 ; \star \star \star p<0.001$.

laminae I-II (Table 1). Although the number of Fos-IR neurons induced was similar in $\mathrm{NK} 1-/-$ and wild-type mice after acute noxious stimulation, there was a higher percentage of evoked Fos-IR neurons in the ipsilateral laminae I-II ([laminae I-II/ipsilateral dorsal horn] $\times 100)$ in the NK1-/- than in the wild-type mice: $47.6 \pm 4.5$ and $37 \pm 1.5 \%$, respectively (Table 1 , Fig. 1), although this did not reach significance $(p=0.0584)$. Figure 2, $A$ and $C$, shows a representation of this pattern of Fos expression in the superficial laminae. Similar differences were obtained after treatment of wild-type mice with an NK1 antagonist compared with its inactive isomer. The number of Fos-IR neurons induced and the percentage of Fos expression in the laminae I-II were not significantly different between these groups (Fig. 3A).

\section{Effect of noxious heat applied to the forepaw}

An acute $(40 \mathrm{sec})$ noxious stimulation of $50^{\circ} \mathrm{C}$ applied to the forepaw did not induce significant c-Fos expression at the lumbar level in wild-type mice. It evoked c-Fos expression in a small but significant $(p<0.01)$ number of neurons in the superficial laminae of the ipsilateral spinal cord of NK1-/- mice (Fig. 3). 
Influence of noxious heat applied to the forepaw on c-Fos expression evoked at the lumbar level by stimulation of the hindpaw

To summarize the protocol, an acute $(10 \mathrm{sec})$ noxious heat $\left(50^{\circ} \mathrm{C}\right)$ stimulation of the hindpaw was delivered while an acute conditioning $(40 \mathrm{sec})$ noxious heat $\left(50^{\circ} \mathrm{C}\right)$ stimulation was applied to the forepaw. These experimental conditions resulted in a lower number of Fos-IR neurons evoked at the lumbar level in wildtype but not NK1-/- mice ( $p<0.001$; Table 1, Figs. $1 A 2, B 2$, $2 B, D, 3 C)$.

Laminae I-II. In wild-type mice, the number of Fos-IR neurons evoked at the lumbar level after concurrent stimulation of the forepaw and hindpaw was significantly lower $(p<0.001)$ than that evoked when the hindpaw only was stimulated (Table 1, Figs. $1 A 1, A 2,2,4)$. Indeed, the concurrent forepaw stimulation resulted in a hindpaw stimulation-induced number of Fos-IR neurons of $45.4 \%$ of the control value, i.e., corresponding to a substantial decrease of $54.6 \%$.

In contrast, in NK1-/- mice, the conditioning noxious stimulation of the forepaw had no effect on the noxiously evoked (acute) c-Fos expression in the spinal laminae I-II at the lumbar level. Indeed, the hindpaw stimulation evoked a similar number of Fos-IR neurons in these laminae I-II, whether it was applied alone or in combination with a forepaw conditioning noxious stimulation (Table 1, Figs. 1B1,B2, 2, 4). In wild-type mice, the number of Fos-IR neurons in the lumbar cord was low and independent of the number of Fos-IR neurons seen in the cervical cord (Fig. 5). In contrast, in NK1 $-/-$ mice, the number of For-IR neurons in the lumbar cord was directly proportional to the number of cervical Fos-IR neurons.

Laminae V-VI. In wild-type mice, concurrent noxious heat stimuli given to the forepaw also contributed to a significant reduction $(p=0.04)$ in the number of Fos-IR neurons induced by a hindpaw stimulation in the laminae V-VI of the dorsal horn (Table 1). Such an effect was not observed in NK1-/- mice.

\section{Use of NK1 antagonists in wild-type mice}

Absence of noxiously evoked descending inhibitory controls after acute pain were also observed when using an NK1 antagonist (RP67580), but not its inactive isomer (RP68651). At lumbar levels, the number of Fos-IR neurons induced by a hindpaw only or forepaw plus hindpaw stimuli together were not significantly different in the NK1 antagonist-treated group (Table 1, Figs. $1 C, D, 3 C, 4)$, as was the case in $\mathrm{NK} 1$ receptor knock-out mice. In contrast, in the inactive isomer-treated group, concurrent forepaw stimulation significantly reduced the number of Fos-IR neurons evoked by a hindpaw $50^{\circ} \mathrm{C}$ stimulation. This was also the case in untreated wild-type mice. The above results indicate that NK1 transmission is required for full development of noxiously evoked descending inhibitory controls of acute nociception at the spinal cord level, as revealed by c-Fos expression.

C-Fos induction at the cervical level. A short noxious stimulation of the hindpaw did not result in significant c-Fos expression in the laminae I-II of the cervical cord in either wild-type or NK1-/mice (Fig. 6). Applying $50^{\circ} \mathrm{C}$ to the forepaw for $40 \mathrm{sec}$ induced a large number of Fos-IR neurons in the superficial laminae of the ipsilateral cervical cord (Table 2, Fig. 6). The number of Fos-IR neurons evoked in laminae I-II was not significantly different between NK1-/- and wild-type mice.

In wild-type and NK1-/- mice, the Fos expression in the cervical laminae I-II neurons evoked by a forepaw noxious stim-

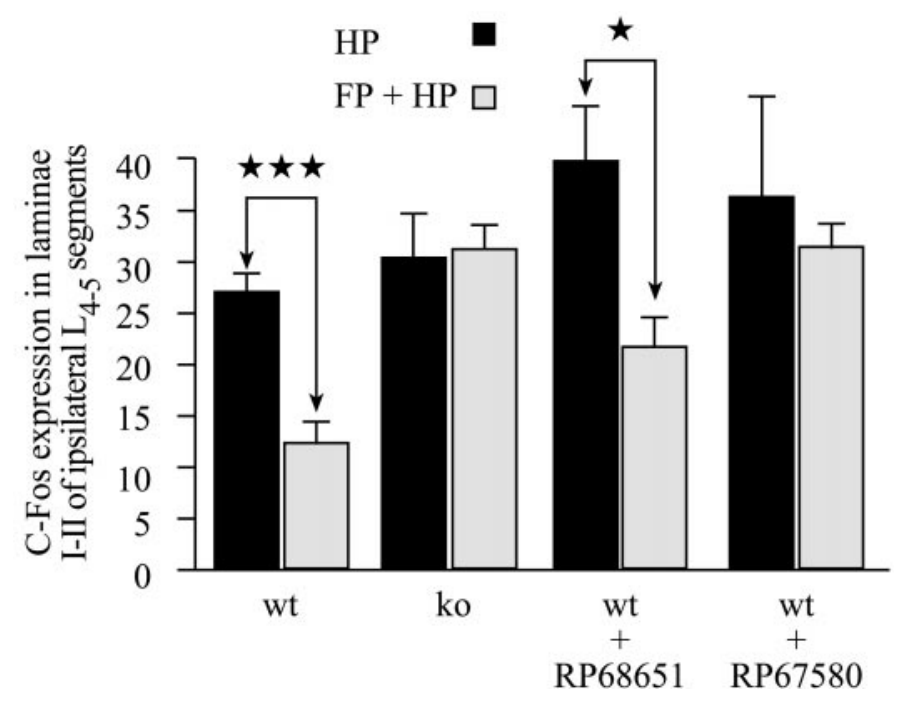

Figure 4. Histograms of the average number per section of Fos-IR neurons evoked in the lumbar laminae I-II, comparing the HP and the FP + HP situations. $\star p<0.05 ; \star \star \star p<0.001$.

ulus was not affected by the concurrent remote noxious stimulation of the hindpaw (Table 2, Fig. 6).

$C$-Fos induction in the RVM. Fos-IR neurons were also observed in the raphe nuclei of the RVM in wild-type and NK1-/mice after concurrent stimulation of the forepaw and hindpaw (Fig. 7A).

The number of Fos-IR neurons evoked by the double stimulation was lower in the NK1-/- mice for all the individual RVM nuclei. The counts in the mutant mice were significantly lower than in wild-type mice in the RPa and RMg nuclei, $(p<0.01$ and $p<0.001$, respectively) (Fig. $7 A$ ). Scattergram of Fos-IR neurons observed in laminae I-II of the lumbar cord versus the number of Fos-IR neurons observed in the RPa and RMg nuclei (Fig. 7B), emphasizes that reduced lumbar Fos expression seen in double stimulated wild-type mice is associated with high levels of Fos expression in the RVM. Conversely, maintained levels of Fos expression in the lumbar dorsal horn of double stimulated

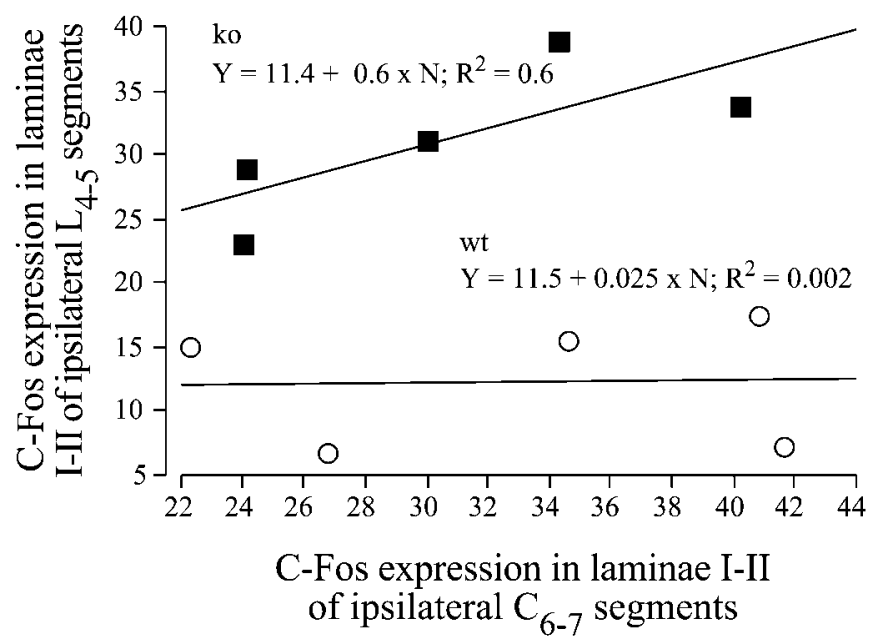

Figure 5. Relationship between lumbar and cervical c-Fos expression in the FP + HP situation. Regression plots and correlation lines and functions of the lumbar against cervical numbers of Fos-IR neurons in laminae I-II. 


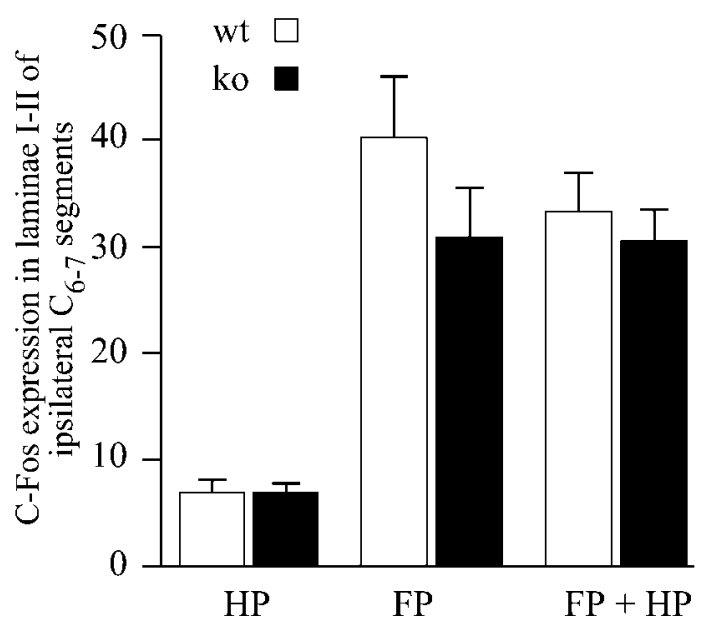

Figure 6. Histograms of the average number per section of Fos-IR neurons evoked in the cervical laminae I-II, in the HP, FP, and FP + HP situations.

NK1 $-/-$ mice are associated with low levels of Fos expression in the RVM.

\section{DISCUSSION}

A substantial amount of research has implicated brain areas including the amygdala, ventromedial nucleus of the hypothalamus (VMH), periaqueductal gray (PAG), and RVM in mediating antinociception generated by opiates, local brain stimulation, and stress-induced analgesia (Kelly and Franklin, 1984; Jones and Light, 1990; Matthes et al., 1996; Fields, 2000; Valverde et al., 2000). Those areas directly or indirectly receive substantial nociceptive input from NK1-expressing projection neurons of the dorsal horn (Bernard and Besson, 1990; Bernard et al., 1993; Bester et al., 1995, 1997a,b; Ding et al., 1995; Li et al., 1998; Todd et al., 2000). Our data implicates SP at different points in this circuit as crucial both for the generation of stress-induced analgesia and noxious inhibitory controls. The results indicate that whereas Fos expression in the dorsal horn after noxious thermal stimulation is at comparable levels in both wild-type and $\mathrm{NK} 1-/-$ mice, there is an absence of descending inhibitory control on Fos expression in mutant mice. This observation was confirmed using NK1 antagonists in wild-type mice, indicating that the knock-out phenotype was not the result of compensatory mechanisms invoked in the absence of the NK1 receptor gene. RVM examination showed a reduction in Fos expression in $\mathrm{NK} 1-/-$ mice, in turn implicating reduced inhibitory controls in mutant mice. These impaired descending inhibitory controls could also account for the increase, although modest, of Fos expression in the lumbar dorsal horn of NK1-/- after forepaw stimulation alone. It is unlikely that Fos expression occurred more readily in mutant mice, because at the cervical level similar numbers of Fos-positive neurons were observed in both genotypes.

\section{SP-generated antinociception}

Reduced descending inhibition in NK1-/- animals could have resulted from a reduced level of neuronal excitation within the spinal cord or brainstem. Lamina I NK1 receptor-bearing cells have specific morphological features (Cheunsuang and Morris, 2000), are involved in acute and chronic pain (Abbadie et al., 1996; Doyle and Hunt, 1999), and have complex relationship to morphine analgesia (Trafton et al., 1999). Coordinated action of SP and glutamate (Kangrga and Randic, 1990; Liu et al., 1997), coreleased from sensory afferents within the spinal cord (Battaglia and Rustioni, 1988; De Biasi and Rustioni, 1988), results in a substantially amplified postsynaptic response (Woolf and Wiesenfeld-Hallin, 1986; Marvizon et al., 1997). This may be lacking in mutant mice. Indeed, in $\mathrm{NK} 1-/-$ or in wild type treated with an NK1 antagonist, there is a loss of "wind-up" in spinal neurons (Xu et al., 1992; Budai and Larson, 1996; De Felipe et al., 1998). Because of a close coupling of activity in ascending and descending pathways, a reduced ascending drive would result, secondarily, in reduced descending inhibitory influence on the spinal cord (Cervero et al., 1991; Schaible et al., 1991).

Reduced descending inhibition in NK1-/- mice could alternatively, and perhaps concurrently, originate directly at the brain level where the NK1 receptor is also widely expressed within brainstem and forebrain areas such as the amygdala, hypothalamus, and PAG (Del Rio et al., 1983; Liu and Swenberg, 1988; Zeng et al., 1991; Maeno et al., 1993; Xin et al., 1997). These brain areas are known to mediate the complex responses of the animal to major environmental stressors, and many of these survival behaviors are blunted in the NK1-/- mouse (De Felipe et al., 1998). Release of SP in these areas would be expected to drive descending inhibitory pathways from the brainstem to the spinal cord generating stress-induced analgesia. Such a role for SP in modulating descending inhibition has been demonstrated in that intracerebroventricular SP injections can lead to antinociception in mice and rats (Stewart et al., 1976, 1982; Oehme et al., 1980, 1982; Meszaros et al., 1981; Naranjo and Del Rio, 1982; Naranjo et al., 1982a,b, 1986, 1989; Del Rio et al., 1983; Rodriguez and Rodriguez, 1989). These results suggest that the NK1 receptor at sites within both the brain and spinal cord are important for the full expression of noxious inhibitory controls.

Table 2. Averages $( \pm$ SEM) of the laminar distribution of the Fos-IR neurons at the cervical level

\begin{tabular}{|c|c|c|c|c|c|c|c|c|c|c|}
\hline \multirow[b]{3}{*}{ Group } & \multirow[b]{3}{*}{ Mice } & \multicolumn{9}{|c|}{ Cervical cord } \\
\hline & & \multicolumn{4}{|c|}{ Ipsilateral dorsal horn } & \multirow[b]{2}{*}{$\mathrm{X}$} & \multicolumn{4}{|c|}{ Contralateral dorsal horn } \\
\hline & & I-II & III-IV & V-VI & $\mathrm{DH}+\mathrm{VH}$ & & I-II & III-IV & $\mathrm{V}-\mathrm{VI}$ & $\mathrm{DH}+\mathrm{VH}$ \\
\hline \multirow[t]{2}{*}{ FP } & wt & $40.4 \pm 6$ & $12.4 \pm 2$ & $15.3 \pm 3.5$ & $83.5 \pm 13$ & $7.2 \pm 1$ & $2.7 \pm 0.6$ & $6.7 \pm 1.2$ & $12.7 \pm 1.8$ & $35.8 \pm 6.7$ \\
\hline & ko & $31 \pm 4.9$ & $29.1 \pm 3.3$ & $19.8 \pm 1.9$ & $103.4 \pm 8.9$ & $8.2 \pm 1$ & $3.9 \pm 0.8$ & $19 \pm 1.9$ & $16.3 \pm 1$ & $61.4 \pm 1.7$ \\
\hline \multirow[t]{2}{*}{$\mathrm{FP}+\mathrm{HP}$} & wt & $33.2 \pm 3.8$ & $19.9 \pm 3.5$ & $11.7 \pm 1.5$ & $73.2 \pm 7$ & $6 \pm 1$ & $4.5 \pm 1.3$ & $14.1 \pm 2.2$ & $12.6 \pm 3.5$ & $41.3 \pm 8.2$ \\
\hline & ko & $30.5 \pm 3.1$ & $28.7 \pm 2.9$ & $18 \pm 2.9$ & $88 \pm 6.7$ & $6.8 \pm 0.9$ & $6.3 \pm 1.3$ & $24.7 \pm 5.8$ & $13 \pm 2$ & $51.9 \pm 9.8$ \\
\hline
\end{tabular}

I-II, III-IV, V-VI, X, Corresponding dorsal horn laminae. DH and VH, Dorsal and ventral horns, respectively. See Figure 1 for protocol abbreviations. 
A

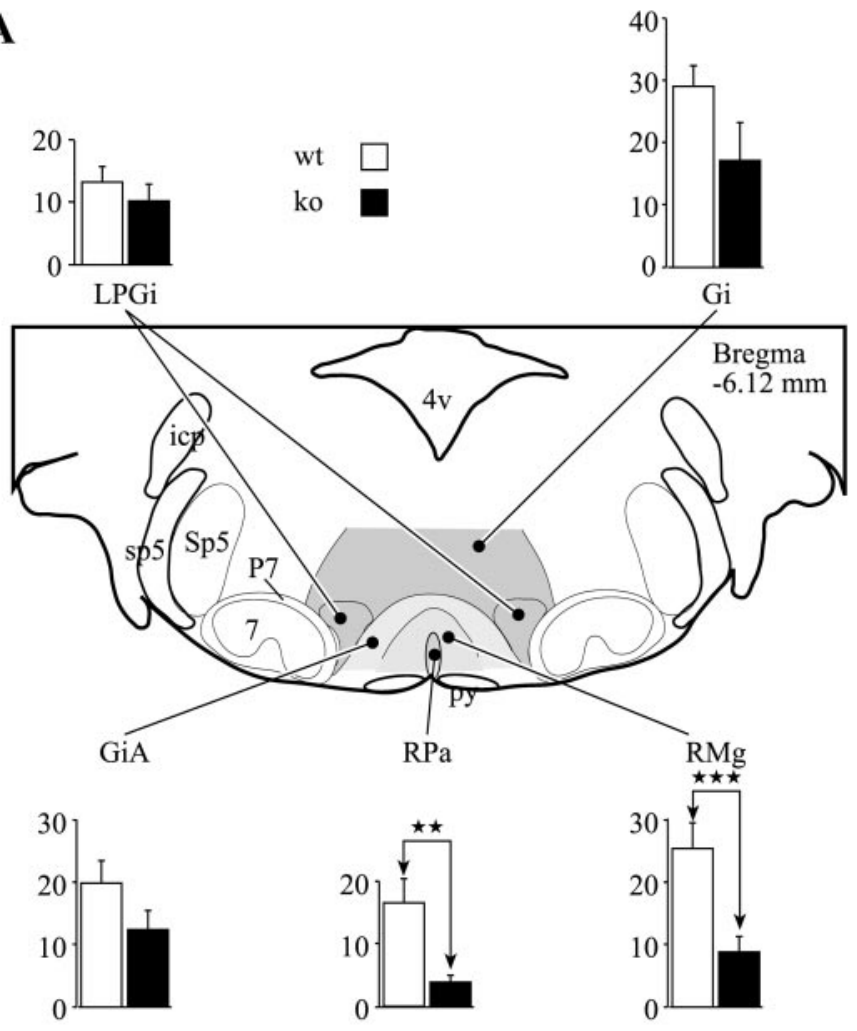

B

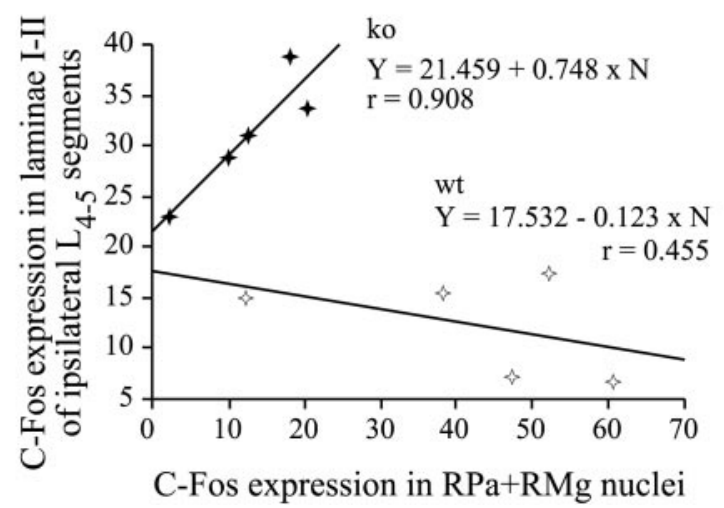

Figure 7. C-Fos expression in the rostral ventromedial medulla and its influence on the c-Fos expression in lumbar laminae I-II in the FP + HP situation. $A$, Histograms of average numbers of Fos-IR neurons observed in different raphe nuclei viewed on a schematic representation of the medulla from the Franklin and Watson (1997) atlas. $\star \star p<0.01$; $\star \star \star p<0.001$. Gi, Gigantocellular reticular; GiA, gigantocellular reticular pars $\alpha ; L P G i$, lateral paragigantocellular reticular; $R M g$, raphe magnus; $R P a$, raphe pallidus. $B$, Correlation plots of the numbers of Fos-IR neurons in the $\mathrm{RPa}$ and $\mathrm{RMg}$ raphe nuclei. Filled symbols correspond to NK1-/- mice; open symbols correspond to wild-type mice.

\section{Organization of the descending inhibitory controls: relationship to DNIC}

It is well established that many spinal neurons can be tonically inhibited by activity in descending pathways and that this activity can be regulated by a variety of influences, including chronic noxious input from the periphery (Danziger et al., 1999). For example, inflammation-evoked hyperexcitability of spinal neurons produced by the afferent input from inflamed knee, as well as the input from unaffected tissues remote from the inflamed joint, is opposed by an enhancement of descending inhibition (Cervero et al., 1991; Schaible et al., 1991). Also, Fos expression, evoked by noxious stimulation of the hindpaw, is greater in spinalized animals, suggesting the presence of a descending inhibitory influence (Ren and Dubner, 1996; Lumb et al., 1997). Fos expression, which has been widely used to map activity within nociceptive pathways (Hunt et al., 1987; Abbadie et al., 1994; Bester et al., 1997b; Harris, 1998), has also been used to confirm the presence of DNIC (Morgan et al., 1994). Within the superficial dorsal horn, Fos expression has been found within both inhibitory interneurons and in projection neurons, reflecting the complexity of descending influences on processing within the dorsal horn (Todd et al., 1994; Sandkühler, 1996).

Supraspinal loops, particularly involving RVM and/or propriospinal pathways can also mediate DNIC and inhibition generated by activity in other parts of the nervous system (Bouhassira et al., 1993; Sandkühler, 1996; Fields, 2000). Our data indicating reduced Fos expression in the RVM coupled to lack of inhibition of lumbar excitation in the DNIC paradigm could support this suggestion. We have shown that in wild-type mice Fos expression in the raphe nuclei was significantly increased in response to noxious stimuli. In contrast, in NK1-/- mice, raphe expression was much reduced and significantly lower in the RPa and RMg nuclei than in wild-type mice. Given that these raphe nuclei have been implicated in descending inhibition (Dostrovsky et al., 1983; Gebhart et al., 1983; Kwiat and Basbaum, 1992; Sandkühler, 1996; Fields, 2000), the reduced activity of these neurons (implied by reduced c-Fos expression) in the NK1-/- mice may lead directly to reduced descending inhibition.

However, whereas a great deal of evidence suggests that supraspinal loops are involved, the anatomical details of such pathways are less clear. For example, spinal or lower medullary transection prevents the development of DNIC measured electrophysiologically from deep dorsal horn neurons, and local injection of morphine in or direct activation of the RVM or PAG have little effect on DNIC (Bouhassira et al., 1988). Yet, such manipulations can specifically modulate spinal cord excitability and inhibit spinal nociception (Aimone and Gebhart, 1986; Jones and Gebhart, 1988; Jensen and Yaksh, 1989; Heinricher et al., 1994). This suggests that Fos histochemistry may be describing a separate pathway related to the phenomenon of descending inhibitory control.

Other regions such as the subnucleus reticularis dorsalis have been proposed to contribute to DNIC monitored at the deep dorsal horn level (Bouhassira et al., 1992), but, in our hands, no significant Fos expression was induced in this area.

The great majority of superficial spinal neurons projecting to the parabrachial (PB) nuclei of the brainstem express the NK1 receptor (Ding et al., 1995; Todd et al., 2000). The PB area, in turn, projects to forebrain regions such as the amygdala and the VMH (Bernard et al., 1993; Bester et al., 1997a) that are thought to be concerned with the affective rather than the discriminative aspects of noxious stimulation (Bernard and Besson, 1990; Huang et al., 1993; Bester et al., 1995, 2000). Supraspinal neurons within this pathway tend to be NS, encode for the intensity of noxious stimulation, and have extremely large receptive fields covering half or more of the body. The PAG, which in turn receives substantial inputs from brain areas such as the VMH and amygdala (Canteras et al., 1994, 1995), activates the RVM (Beitz, 1982; Fort et al., 1994). Disabling the first step of this complex loop (i.e., lamina I neurons) using SP-saporin conjugates (Man- 
tyh et al., 1997; Nichols et al., 1999) was shown to substantially reduce the changes in pain sensitivity that follow peripheral manipulations of the nerve or experimentally induced inflammation. Taken together these results suggest that dorsal horn projection neurons that express the NK1 receptor may be essential for the regulation of spinal excitability via ascending-descending spinal loops.

\section{Conclusion}

Our data provide compelling evidence for a major role of SP and the NK1 receptor in endogenous mechanisms of descending inhibition involving the RVM. The results indicate that SP may play an important role in generating endogenous antinociception and argue against any simple role in nociceptive signaling.

\section{REFERENCES}

Abbadie C, Honoré P, Fournie-Zaluski MC, Roques BP, Besson JM (1994) Effects of opioids and non-opioids on c-Fos-like immunoreactivity induced in rat lumbar spinal cord neurons by noxious heat stimulation. Eur J Pharmacol 258:215-227.

Abbadie C, Brown JL, Mantyh PW, Basbaum AI (1996) Spinal cord substance $\mathrm{P}$ receptor immunoreactivity increases in both inflammatory and nerve injury models of persistent pain. Neuroscience 70:201-209.

Aimone LD, Gebhart GF (1986) Stimulation-produced spinal inhibition from the midbrain in the rat is mediated by an excitatory amino acid neurotransmitter in the medial medulla. J Neurosci 6:1803-1813.

Battaglia G, Rustioni A (1988) Coexistence of glutamate and substance $\mathrm{P}$ in dorsal root ganglion neurons of the rat and monkey. J Comp Neurol 277:302-312.

Beitz AJ (1982) The nuclei of origin of brain stem enkephalin and substance $\mathrm{P}$ projections to the rodent nucleus raphe magnus. Neuroscience 7:2753-2768.

Bernard JF, Besson JM (1990) The spino(trigemino)pontoamygdaloid pathway: electrophysiological evidence for an involvement in pain processes. J Neurophysiol 63:473-490.

Bernard JF, Aldén M, Besson JM (1993) The organization of the efferent projections from the pontine parabrachial area to the amygdaloid complex: a Phaseolus vulgaris leucoagglutinin (PHA-L) study in the rat. J Comp Neurol 329:201-229.

Bester H, Menendez L, Besson JM, Bernard JF (1995) Spino (trigemino) parabrachiohypothalamic pathway: electrophysiological evidence for an involvement in pain processes. J Neurophysiol 73:568-585.

Bester H, Besson JM, Bernard JF (1997a) Organization of efferent projections from the parabrachial area to the hypothalamus: a Phaseolus vulgaris-leucoagglutinin study in the rat. J Comp Neurol 383:245-281.

Bester H, Matsumoto N, Besson JM, Bernard JF (1997b) Further evidence for the involvement of the spinoparabrachial pathway in nociceptive processes: a c-Fos study in the rat. J Comp Neurol 383:439-458.

Bester H, Chapman V, Besson JM, Bernard JF (2000) Physiological properties of the lamina I spinoparabrachial neurons in the rat. J Neurophysiol 83:2239-2259.

Boucher T, Jennings E, Fitzgerald M (1998) The onset of diffuse noxious inhibitory controls in postnatal rat pups: a C-Fos study. Neurosci Lett 257:9-12.

Bouhassira D, Villanueva L, Le Bars D (1988) Intracerebroventricular morphine decreases descending inhibitions acting on lumbar dorsal horn neuronal activities related to pain in the rat. J Pharmacol Exp Ther 247:332-342.

Bouhassira D, Villanueva L, Bing Z, Le Bars D (1992) Involvement of the subnucleus-reticularis-dorsalis in diffuse noxious inhibitory controls in the rat. Brain Res 595:353-357.

Bouhassira D, Bing Z, Le Bars D (1993) Studies of brain structures involved in diffuse noxious inhibitory controls in the rat-the rostral ventromedial medulla. J Physiol (Lond) 463:667-687.

Budai D, Larson AA (1996) Role of substance P in the modulation of C-fiber-evoked responses of spinal dorsal horn neurons. Brain Res 710:197-203.

Canteras NS, Simerly RB, Swanson LW (1994) Organization of projections from the ventromedial nucleus of the hypothalamus: a Phaseolus vulgaris-leucoagglutinin study in the rat. J Comp Neurol 348:41-79.

Canteras NS, Simerly RB, LW Swanson (1995) Organization of projections from the medial nucleus of the amygdala - a Phal study in the rat. J Comp Neurol 360:213-245.

Cervero F, Schaible HG, Schmidt RF (1991) Tonic descending inhibition of spinal cord neurons driven by joint afferents in normal cats and in cats with an inflamed knee joint. Exp Brain Res 83:675-678.

Cheunsuang O, Morris R (2000) Spinal lamina I neurons that express neurokinin 1 receptors: morphological analysis. Neuroscience $97: 335-345$.
Danziger N, Weil-Fugazza J, Le Bars D, Bouhassira D (1999) Alteration of descending modulation of nociception during the course of monoarthritis in the rat. J Neurosci 19:2394-2400.

De Biasi S, Rustioni A (1988) Glutamate and substance P coexist in primary afferent terminals in the superficial laminae of spinal cord. Proc Natl Acad Sci USA 85:7820-7824.

De Felipe C, Herrero JF, O'Brien JA, Palmer JA, Doyle CA, Smith AJH, Laird JMA, Belmonte C, Cervero F, Hunt SP (1998) Altered nociception, analgesia and aggression in mice lacking the receptor for substance P. Nature 392:394-397.

Del Rio J, Naranjo JR, Yang HY, Costa E (1983) Substance P-induced release of Met5-enkephalin from striatal and periaqueductal gray slices. Brain Res 279:121-126.

Ding YQ, Takada M, Shigemoto R, Mizumo N (1995) Spinoparabrachial tract neurons showing substance $\mathrm{P}$ receptor-like immunoreactivity in the lumbar spinal cord of the rat. Brain Res 674:336-340.

Dostrovsky JO, Shah Y, Gray BG (1983) Descending inhibitory influences from periaqueductal gray, nucleus raphe magnus, and adjacent reticular formation. II. Effects on medullary dorsal horn nociceptive and nonnociceptive neurons. J Neurophysiol 49:948-960.

Doyle CA, Hunt SP (1999) Substance P receptor (neurokinin-1)expressing neurons in lamina I of the spinal cord encode for the intensity of noxious stimulation: a c-Fos study in rat. Neuroscience $89: 17-28$.

Fields HL (2000) Pain modulation: expectation, opioid analgesia and virtual pain. Prog Brain Res 122:245-253.

Foo H, Helmstetter FJ (1999) Hypoalgesia elicited by a conditioned stimulus is blocked by a mu, but not a delta or a kappa, opioid antagonist injected into the rostral ventromedial medulla. Pain 83:427-431.

Foo H, Helmstetter FJ (2000) Expression of antinociception in response to a signal for shock is blocked after selective downregulation of mu-opioid receptors in the rostral ventromedial medulla. Brain Res Mol Brain Res 76:282-288.

Fort P, Luppi PH, Jouvet M (1994) Afferents to the nucleus reticularis parvicellularis of the cat medulla oblongata: a tract-tracing study with cholera toxin B subunit. J Comp Neurol 342:603-618.

Franklin KBJ, Paxinos G (1997) The mouse brain atlas in stereotaxic coordinates. New York: Academic.

Gebhart GF, Sandkühler J, Thalhammer JG, Zimmermann M (1983) Inhibition of spinal nociceptive information by stimulation in midbrain of the cat is blocked by lidocaine microinjected in nucleus raphe magnus and medullary reticular formation. $J$ Neurophysiol 50:1446-1459.

Gerhart KD, Yezierski RP, Giesler GJJ, Willis WD (1981) Inhibitory receptive fields of primate spinothalamic tract cells. J Neurophysiol 46:1309-1325

Harris JA (1998) Using c-fos as a neural marker of pain. Brain Res Bull 45:1-8.

Heinricher MM, Morgan MM, Tortorici V, Fields HL (1994) Disinhibition of off-cells and antinociception produced by an opioid action within the rostral ventromedial medulla. Neuroscience 63:279-288.

Huang GF, Besson JM, Bernard JF (1993) Morphine depresses the transmission of noxious messages in the spino(trigemino)-pontoamygdaloid pathway. Eur J Pharmacol 230:279-284.

Hunt SP, Pini A, Evan G (1987) Induction of c-fos-like protein in spinal cord neurons following sensory stimulation. Nature 328:632-634.

Hurley RW, Hammond DL (2000) The analgesic effects of supraspinal $\mathrm{mu}$ and delta opioid receptor agonists are potentiated during persistent inflammation. J Neurosci 20:1249-1259.

Jensen TS, Yaksh TL (1989) Comparison of the antinociceptive effect of morphine and glutamate at coincidental sites in the periaqueductal gray and medial medulla in rats. Brain Res 476:1-9.

Jones SL, Light AR (1990) Electrical stimulation in the medullary nucleus raphe magnus inhibits noxious heat-evoked fos protein-like immunoreactivity in the rat lumbar spinal cord. Brain Res 530:335-338.

Jones SL, Gebhart GF (1988) Inhibition of spinal nociceptive transmission from the midbrain, pons and medulla in the rat: activation of descending inhibition by morphine, glutamate and electrical stimulation. Brain Res 460:281-296.

Kangrga I, Randic M (1990) Tachykinins and calcitonin gene-related peptide enhance release of endogenous glutamate and aspartate from the rat spinal dorsal horn slice. J Neurosci 10:2026-2038.

Kelly SJ, Franklin KB (1984) Electrolytic raphe magnus lesions block analgesia induced by a stress-morphine interaction but not analgesia induced by morphine alone. Neurosci Lett 52:147-152.

Kwiat GC, Basbaum AI (1992) The origin of brainstem noradrenergic and serotonergic projections to the spinal cord dorsal horn in the rat. Somatosens Mot Res 9:157-173.

Le Bars D, Dickenson AH, Besson JM (1979) Diff use noxious inhibitory controls (DNIC). I. Effects on dorsal horn convergent neurons in the rat. Pain 6:283-304.

Li JL, Ding YQ, Xiong KH, Li JS, Shigemoto R, Mizuno N (1998) Substance P receptor (NK1)-immunoreactive neurons projecting to the 
periaqueductal gray: distribution in the spinal trigeminal nucleus and the spinal cord of the rat. Neurosci Res 30:219-225.

Liu H, Mantyh PW, Basbaum AI (1997) NMDA-receptor regulation of substance $P$ release from primary afferent nociceptors. Nature 386:721-724.

Liu RP, Swenberg ML (1988) Autoradiographic localization of substance $\mathrm{P}$ ligand binding sites and distribution of immunoreactive neurons in the periaqueductal gray of the rat. Brain Res 475:73-79.

Lumb BM, J O'Brien, Hunt SP (1997) The effects of spinalization and naloxone pretreatment on Fos expression in the rat spinal cord following noxious stimulation. J Physiol (Lond) 505:40.P.

Maeno H, Kiyama H, Tohyama M (1993) Distribution of the substance $\mathrm{P}$ receptor (NK-1 receptor) in the central nervous system. Brain Res Mol Brain Res 18:43-58.

Mantyh PW, Rogers SD, Honoré P, Allen BJ, Ghilardi JR, Li J, Daughters RS, Lappi DA, Wiley RG, Simone DA (1997) Inhibition of hyperalgesia by ablation of lamina I spinal neurons expressing the substance P receptor [see comments]. Science 278:275-279.

Marvizon JC, Martinez V, Grady EF, Bunnett NW, Mayer EA (1997) Neurokinin 1 receptor internalization in spinal cord slices induced by dorsal root stimulation is mediated by NMDA receptors. J Neurosci 17:8129-8136

Matthes HW, Maldonado R, Simonin F, Valverde O, Slowe S, Kitchen I, Befort K, Dierich A, Le Meur M, Dolle P, Tzavara E, Hanoune J, Roques BP, Kieffer BL (1996) Loss of morphine-induced analgesia, reward effect and withdrawal symptoms in mice lacking the mu-opioidreceptor gene. Nature 383:819-823.

Meszaros J, Tarchalska B, Gajewska S, Janicki P, Duriasz H, Szreniawski Z (1981) Substance P, hexapeptide pGlu6(SP6-11), analgesia and serotonin depletion. Pharmacol Biochem Behav 14:11-15.

Molander C, Xu Q, Grant G (1984) The cytoarchitectonic organization of the spinal cord in rat. I. The lower thoracic and lumbosacral cord. J Comp Neurol 230:133-141.

Morgan MM, Gogas KR, Basbaum AI (1994) Diffuse noxious inhibitory controls reduce the expression of noxious stimulus-evoked Fos-like immunoreactivity in the superficial and deep laminae of the rat spinal cord. Pain 56:347-352.

Naranjo JR, Del Rio J (1982) Differential effects of D-Ala2 analogues of enkephalins on substance P-induced analgesia in rodents. Eur J Pharmacol 82:213-216.

Naranjo JR, Sanchez-Franco F, Del Rio J (1982a) Blockade by metenkephalin antiserum of analgesia induced by substance $\mathrm{P}$ in mice. Neuropharmacology 21:1295-1299.

Naranjo JR, Sanchez-Franco F, Garzon J, Del Rio J (1982b) Analgesic activity of substance $\mathrm{P}$ in rats: apparent mediation by met-enkephalin release. Life Sci 30:441-446.

Naranjo JR, Arnedo A, De Felipe MC, Del Rio J (1986) Antinociceptive and Met-enkephalin releasing effects of tachykinins and substance $\mathrm{P}$ fragments. Peptides 7:419-423.

Naranjo JR, Arnedo A, Molinero MT, Del Rio J (1989) Involvement of spinal monoaminergic pathways in antinociception produced by substance $\mathrm{P}$ and neurotensin in rodents. Neuropharmacology 28:291-298.

Ness TJ, Gebhart GF (1991) Interactions between visceral and cutaneous nociception in the rat. II. Noxious visceral stimuli inhibit cutaneous nociceptive neurons and reflexes. J Neurophysiol 66:29-39.

Nichols ML, Allen BJ, Rogers SD, Ghilardi JR, Honoré P, Luger NM, Finke MP, Li J, Lappi DA, Simone DA, Mantyh PW (1999) Trans- mission of chronic nociception by spinal neurons expressing the substance P receptor. Science 286:1558-1561.

Oehme P, Hilse H, Morgenstern E, Gores E (1980) Substance P: does it produce analgesia or hyperalgesia? Science 208:305-307.

Oehme P, Hecht K, Piesche L, Hilse H, Rathsack R (1982) Relation of substance P to stress and catecholamine metabolism. Ciba Found Symp 296-306.

Ren K, Dubner R (1996). Enhanced descending modulation of nociception in rats with persistent hindpaw inflammation. J Neurophysiol 76:3025-3037.

Roby Brami A, Bussel B, Willer JC, Le Bars D (1987) An electrophysiological investigation into the pain-relieving effects of heterotopic nociceptive stimuli. Probable involvement of a supraspinal loop. Brain 110:1497-1508

Rodriguez FD, Rodriguez RE (1989) Intrathecal administration of 5,6DHT or 5,7-DHT reduces morphine and substance P-antinociceptive activity in the rat. Neuropeptides 13:139-146.

Sandkühler J (1996) The organization and function of endogenous antinociceptive systems. Prog Neurobiol 50:49-81.

Schaible HG, Neugebauer V, Cervero F, Schmidt RF (1991) Changes in tonic descending inhibition of spinal neurons with articular input during the development of acute arthritis in the cat. J Neurophysiol 66:1021-1032.

Stewart JM, Getto CJ, Neldner K, Reeve EB, Krivoy WA, Zimmermann E (1976) Substance P and analgesia. Nature 262:784-785.

Stewart JM, Hall ME, Harkins J, Frederickson RC, Terenius L, Hökfelt T, Krivoy WA (1982) A fragment of substance P with specific central activity: SP(1-7). Peptides 3:851-857.

Todd AJ, Spike RC, Brodbelt AR, Price RF, Shehab SA (1994) Some inhibitory neurons in the spinal cord develop c-fos-immunoreactivity after noxious stimulation. Neuroscience 63:805-816.

Todd AJ, McGill MM, Shehab SA (2000) Neurokinin 1 receptor expression by neurons in laminae I, III and IV of the rat spinal dorsal horn that project to the brainstem. Eur J Neurosci 12:689-700.

Tomlinson RW, Gray BG, Dostrovsky JO (1983) Inhibition of rat spinal cord dorsal horn neurons by non-segmental, noxious cutaneous stimuli. Brain Res 279:291-294.

Trafton JA, Abbadie C, Marchand S, Mantyh PW, Basbaum AI (1999) Spinal opioid analgesia: how critical is the regulation of substance $\mathrm{P}$ signaling? J Neurosci 19:9642-9653.

Valverde O, Ledent C, Beslot F, Parmentier M, Roques BP (2000) Reduction of stress-induced analgesia but not of exogenous opioid effects in mice lacking CB1 receptors. Eur J Neurosci 12:533-539.

Woolf C, Wiesenfeld-Hallin Z (1986) Substance P and calcitonin generelated peptide synergistically modulate the gain of the nociceptive flexor withdrawal reflex in the rat. Neurosci Lett 66:226-230.

Xin L, Geller EB, Liu Chen LY, Chen C, Adler MW (1997) Substance $\mathrm{P}$ release in the rat periaqueductal gray and preoptic anterior hypothalamus after noxious cold stimulation: effect of selective mu and kappa opioid agonists. J Pharmacol Exp Ther 282:1055-1063.

Xu XJ, Dalsgaard CJ, Wiesenfeld-Hallin Z (1992) Spinal substance P and $N$-methyl-D-aspartate receptors are coactivated in the induction of central sensitization of the nociceptive flexor reflex. Neuroscience 51:641-648.

Zeng SL, Li YQ, Rao ZR, Shi JW (1991) Projections from serotoninand substance P-like immunoreactive neurons in the midbrain periaqueductal gray onto the nucleus reticularis gigantocellularis pars alpha in the rat. Neurosci Lett 131:205-209. 